\title{
Alliance Network Diversity and Innovation Ambidexterity: The Differential Roles of Industrial Diversity, Geographical Diversity, and Functional Diversity
}

\author{
Guiyang Zhang ${ }^{1, *}$, Chaoying Tang ${ }^{2, *}$ and Yong $\mathrm{Qi}^{3}$ \\ 1 School of Economics and Management, Nanjing University of Science and Technology, \\ Nanjing 210094, China \\ 2 School of Economics and Management, University of Chinese Academy of Sciences, Beijing 100190, China \\ 3 School of Intellectual Property, Nanjing University of Science and Technology, Nanjing 210094, China; \\ qyong@njust.edu.cn \\ * Correspondence: zhangguiyang14@njust.edu.cn (G.Z.); tcy@ucas.ac.cn (C.T.)
}

Received: 4 January 2020; Accepted: 28 January 2020; Published: 1 February 2020

check for updates

\begin{abstract}
Innovation ambidexterity, namely, performing exploitative and exploratory innovation simultaneously, is important for high-tech firms to achieve sustainable success. This can be achieved by building an egocentric alliance network. Research into the influence of alliance network diversity on innovation ambidexterity is seeing more attention. However, the differences among multiple alliance network diversities are unclear. Grounded on a knowledge-based view, organizational learning theory, and transaction cost theory, this study investigates in-depth the roles of geographical diversity, industrial diversity, and functional diversity of the alliance network. The empirical analysis based on panel data, including alliance data from the SDC Joint \& Venture database and patent data from the Derwent Innovation Index database of 106 top high-tech firms from electronic information and biopharmaceutical industries, suggests that industrial diversity enhances firm innovation ambidexterity, geographical diversity impedes firm innovation ambidexterity, and functional diversity shows an inverted U-shaped relationship with firm innovation ambidexterity. These results provide practical suggestions about alliance network diversity configuration and innovation ambidexterity construction for high-tech firms.
\end{abstract}

Keywords: alliance network; innovation ambidexterity; industrial diversity; geographical diversity; functional diversity

\section{Introduction}

Innovation ambidexterity refers to the ability to engage in both exploratory and exploitative innovation [1,2]. Exploration depends on new knowledge and creative insights developed through acts of experimentation and discovery, whereas exploitation builds on existing knowledge through acts of refinement and gradual improvement [3]. Innovation ambidexterity, as a dynamic capability, is increasingly essential for high-tech firms in an era of high technological turbulence [4]. High-tech firms need to improve exploratory and exploitative innovation at the same time to achieve sustainable development [5]. The antecedents of innovation ambidexterity received research attention decades ago [6]. Internal factors, including strategic orientations [7], top management team diversity [8] and frame flexibility [9], knowledge accumulation [10], and decentralized architecture [11], are found essential to ambidexterity. In the age of open innovation, external knowledge sourcing is increasingly important [12,13]. Egocentric alliance network attributes [14-16], including network 
composition [17,18], network capability [19,20], network embeddedness [21], network position [22], network brokerage, network tie strength [23], and network dynamics [24], were also found to impact ambidexterity.

Recently, increasing attention is being paid to alliance network diversity. Researchers have considered various dimensions of alliance network diversity from the perspectives of partner attributes and alliance attributes [25], including partner type diversity, technological diversity, industrial diversity, geographical diversity, and functional diversity [26,27]. Partner type diversity indicates the diversification of partners including business partners, customers, suppliers, competitors, and venture capital firms, and knowledge partners including universities, research institutions, technology intermediaries, intellectual property organizations, and government agencies. The fact that knowledge partners mainly engage in $R \& D$ activities, while business partners primarily engage in production, marketing, or financing suggests that partner type diversity could be reflected by functional diversity. Furthermore, technological diversity mainly indicates the diversification of technology affiliated with alliance partners, which can be reflected by the industrial and national background of partners in the global industry division of innovation. In this respect, it may overlap with industrial diversity and geographical diversity. As such, the industrial diversity, geographical diversity, and functional diversity, which indicate the diversification of industrial background, national background of network partners, and functional attributes of alliance activities, respectively, are investigated in this study.

All these three types of alliance network diversity have been found to impact firm innovation performance [26-30]. Grounding knowledge-based and dynamic capabilities-based views, Jiang et al. [26] argued that increased industrial diversity and geographical diversity would provide broadened knowledge stock and learning benefits, but also incur added complexity and coordination costs. Functional diversity results in a more balanced portfolio of exploration and exploitation activities that expand the firm's knowledge base, while increased governance diversity inhibits learning and routine building. Deriving from the perspective of transaction cost theory, Cui and O'Connor [28] found that functional diversity negatively interacts with resource diversity in influencing firm innovation. By integrating the organizational learning theory, resource-based view, and transaction cost theory, Huang et al. [30] suggested that industrial heterogeneity and geographical diversity are both positively associated with innovative performance, but the strength of this association is contingent. To summarize, the existing literature is somewhat helpful in guiding firms' practices in innovation, but no systematic, consistent empirical findings or theoretical consensus has formed. Apart from open innovation theory, some scholars illustrated the positive impact of alliance network diversity from the theoretical perspectives of the knowledge-based view [28] and organizational learning theory [29]. Some scholars analyzed its adverse effects from the perspective of transaction cost theory [31]. A few other scholars also studied this issue from the perspectives of network concept [32], social capital theory [33], and dynamic capability theory [26].

However, concerning to innovation ambidexterity, the extant researches about the influence of the alliance network diversity are still in an earlier phase. There are two points. First, although some scholars have distinguished exploitative and exploratory innovation and empirically verified the different impacts of alliance network diversity on them [34], most ambidexterity relevant studies, namely, the balance between exploitative and exploratory innovation, are limited to phenomena description and theoretical hypothesis. Simsek [6] tentatively put forward that network diversity might be a critical factor in building innovation ambidexterity. Lavie and Rosenkopf [35] pointed out that firms can operate in multiple functional alliances that involve both exploitation and exploration activities to realize ambidexterity. Recently, some empirical studies were conducted. Peng and $\mathrm{Wu}$ [36], for instance, empirically found that Chinese latecomer firms could achieve innovation ambidexterity incrementally through developing partner and value function diversity in the global production alliance network. Lucena and Roper [37] supposed that R\&D alliance network diversity generates knowledge-provision effects and learning-experience effects, both of which help improve firm innovation ambidexterity. Ardito et al. [38] suggested that geographical diversity shows double-edged effects by leading to 
redundant knowledge acquisition as well as transaction costs. Despite that, it is worth noting that extant empirical studies either take exploitation and exploration as two variables or measure the ambidexterity through questionnaires. Furthermore, the detailed theoretical building process varies a lot across different studies and lacks integration.

Second, although scholars have defined multiple kinds of alliance network diversity, the differential roles of them in innovation ambidexterity are still unclear. Quite a few empirical studies involved two or more kinds of alliance network diversity simultaneously and found the variance of their influences and influence mechanisms on innovation performance (e.g., [1,26,30,34]). For example, Van Beer and Zand [34] found that geographical diversity and functional diversity act through different channels. Geographical diversity results in successful adaptions of existing products to different local requirements, such as technical standards, market regulations, and customer preferences. Functional diversity leads to a variety of knowledge intake and synergetic effects necessary to develop and commercialize novel products. Huang et al. [30] found that although both industrial diversity and geographical diversity positively associate innovative performance, the impacts of industrial diversity is more stable while the strength of geographical diversity is moderated by environmental turbulence. However, few of them differentiate the roles of each kind of alliance network diversity in innovation ambidexterity construction. In this study, we attempt to address the above research gap by elucidating the differential impacts of industrial diversity, geographical diversity, and functional diversity on innovation ambidexterity.

\section{Literature Review and Hypotheses}

\subsection{Alliance Network Industrial Diversity and Innovation Ambidexterity}

Previous scholars have found that the utilization of external knowledge depends on organizational learning and absorptive capacity [39] and partners from the same industry with high technological similarity, familiar routines, and cooperation synergies can more easily integrate knowledge [26,40]. Driving from transaction cost theory, most scholars argued that alliance network industrial diversity might cause resource misfits or lack of synergies, which may increase the collaboration difficulties and impede the alliance performance. Meanwhile, grounding on the knowledge-based view, they also pointed out that industrial diversity provides knowledge access benefits, which may promote firm innovation. Considering that, they proposed a $\mathrm{U}$ or inverted $\mathrm{U}$ correlation between alliance network industrial diversity and firm innovation $[26,30,40,41]$ and verified it empirically.

However, most previous studies of industrial diversity and innovation did not distinguish exploratory innovation and exploitation, let alone addressed the issue of innovation ambidexterity. The construction of innovation ambidexterity requires firms to perform exploratory and exploitative innovation simultaneously [5]. Having exploitative innovation is quite easy for firms with accumulated knowledge in fields because it can be achieved through exploiting knowledge within firms. Meanwhile, having exploratory innovation requires more effort since it needs firms to access new knowledge and have the absorptive capacity and ability to utilize it. Thus, innovation ambidexterity asks firms to make more effort on exploratory innovation. According to the knowledge-based view, producing exploratory innovation that involves breakthrough technologies through the integration of similar knowledge is nearly impossible [30]. The diversity of knowledge sources is necessary for exploratory innovation [42]. The most critical source of the knowledge spillover effect is outside the industry, and agglomeration among different industries can promote the spillover of heterogeneous knowledge [43]. Industrial heterogeneity reflects the differentiation of technical knowledge [30]. It enhances the possibilities of identifying fruitful and novel knowledge combinations that lead to exploratory innovation [40]. Thus, it helps improve innovation ambidexterity.

Besides, grounding on organizational learning theory, allying with diversified inter-industry alliances helps to develop experience, awareness, and understanding of differences among partners and make focal firms more attentive in recognizing and addressing ambiguity and complexity in 
their egocentric alliance network [44]. Firms become more accustomed to identifying and resolving tensions in alliances and in addressing these by modifying existing alliance routines and develop new ones [40]. In this sense, industrial diversity may not increase transaction costs as firms become more adept at dealing with such costs through learning. The fact is that transaction costs also exist in intra-industry alliances and even more than inter-industry alliances. Partners from the same industry are often competitors with an overlap in business backgrounds, innovation experiences, knowledge accumulation, and technological bases ([39]), which may cause conflicts of interest and learning races [45], increase monitoring and safeguarding cost, make alliance cooperation complex $([26,30])$. In contrast, allying with partners from unrelated industries can decrease cooperation conflicts and increase knowledge learning.

To conclude, based on knowledge-based view and organizational learning theory, alliance network industrial diversity fosters knowledge-provision effects and learning-experience effects. Based on the transaction cost theory, industrial diversity also decreases conflicts and costs. As such, it benefits firm innovation ambidexterity. We, therefore, put forward the following hypothesis:

Hypothesis 1. Alliance network industrial diversity positively impacts firm innovation ambidexterity.

\subsection{Alliance Network Geographical Diversity and Innovation Ambidexterity}

Grounding on knowledge-based view and organizational learning theory, previous studies pointed out that geographical diversity provides geographically dispersed knowledge that is lacking in the home state and improves and improving flexibility, responsiveness, and adaptability to foreign markets [46-49]. Notwithstanding the above benefits, geographical diversity also entails unique challenges from the perspective of transaction cost theory. Unlike industrial diversity or others, geographical diversity stems from different geographical locations, cultures, institutional systems, and economic development between nations [48]. Therefore, it is bound to generate higher costs and more difficulties [30].

First, high geographical diversity can pose a high potential for conflicts and increase transaction costs. Comparing with domestic partners, cross-broader partners have more differences in societal and cultural institutions, political and economic systems, national industry structures, and government policies [50], which may result in divergence in priorities and expectations, and eventually in lack of commitment and irresolvable conflicts [32]. Tung [51], for instance, contrasted different communication patterns between Americans and Japanese top managers and highlighted the difficulties in the interaction and acculturation process involving partners from different countries. Allying with partners from diversified nations requires higher costs in means of communication to support integration [48]. Some scholars pointed out that countries at different development stages adopt different innovation patterns, that is, developed countries prefer the development and implementation of advanced technologies [52] while emerging countries such as China or India tend to do frugal innovation [53]. Such disparity in levels of economic development and appropriability regimes in partners' home nations increases the risk of undesirable knowledge spillover and misappropriation of value [54]. Furthermore, cultural and linguistic barriers hinder objective alignment since they may create causal ambiguity, distrust, and opportunism [38]. All of them would lead to higher alliance transaction and governance costs.

Second, high geographical diversity increases the difficulty of inter-organizational learning. Differences in societal and cultural institutions, political and economic systems, national industry structures, and government policies between the focal firm and cross-broader partners limit familiarity, trust and the scope of shared values and goals that are needed to elicit positive attitudes, simulate learning motivation, and facilitate social exchange in alliances [50]. Cultural and linguistic barriers add to the cognitive and managerial barriers that reduce focal firms' propensity to pursue the exploratory learning avenues provided by externally geographical dispersed knowledge [38]. Furthermore, 
information asymmetries may be exploited by cross-broader partners that possess superior knowledge of local customers' preferences, the positions of local competitors, and the regulatory environment in their countries, which increase the focal firm's dependence on their partners and make learning more challenging [55]. In turn, these liabilities increase the difficulty and reduce the effectiveness of organizational learning in alliances.

Although some studies empirically have found that geographical diversity leads to high innovation performance [30,49], most of them did not address the issue of the novelty of innovation or distinguish exploratory innovation and exploitative innovation. According to Sarpong and Teirlinck's [42] findings, geographical diversity may not enhance the balance between both exploitative and exploratory innovation. Grounding on transaction cost theory and organizational learning theory, we propose that high geographical diversity increases the cost of coordination and the difficulty of inter-organizational learning, both of which impede the innovation, especially the exploratory innovation that requires higher-order coordination and inter-organizational learning. As such, it may decrease innovation ambidexterity. We, therefore, put forward the following hypothesis:

Hypothesis 2. Alliance network geographical diversity negatively impacts firm innovation ambidexterity.

\subsection{Alliance Network Functional Diversity and Innovation Ambidexterity}

Egocentric alliance networks can serve different functional purposes. For example, alliances that involve production, marketing, and financing are employed to enhance value creation, enter new markets, and further exploit existing competencies [56]. Alliances involve R\&D functions are employed to generate new knowledge, develop new technologies, and explore new competencies [57]. Grounding on the nature of exploitation and exploration, some scholars distinguished the exploitative alliance and exploratory alliance according to their alliance function. Jiang et al. [26], for instance, argued that the R\&D alliance relates to exploration while the marketing, manufacturing, and distribution alliance relate to exploitation. Lucena and Roper [37] distinguished roles of ' $\mathrm{R}$ ' (research) and ' $\mathrm{D}$ ' (develop) in terms of exploitation and exploration. ' $\mathrm{R}$ ' relates to exploitation as it includes exploration intended to discover and use new knowledge sources, while ' $\mathrm{D}$ ' relates to exploration as it includes exploitation aimed to utilize existing knowledge for improving current products and technologies. Despite the tiny difference in the definition of the exploitative and exploratory alliance, there is a consensus that an alliance network involving diversified functions is more balanced in exploitation and exploitation [26,37].

From the perspective of knowledge-based view and organizational learning theory, previous studies empirically found that the functional diversity involving both exploitation and exploration positively associates with the presence of ambidexterity [35-37]. High functional diversity enables the focal firm to access complementary and supplementary knowledge resulting from both upstream and downstream activities along the innovation value chain [58]. It expands the knowledge pool, from which the focal firm can learn how to adjust, improve, and leverage their competences [37]. The focal firm can exploit its current viability through marketing or production, explore its future viability through $R \& D$, and in turn, achieve a balance between exploitation innovation and exploratory innovation.

However, as already pointed out, the primary alliance activity that fosters exploration is R\&D, or even ' $R$ ' only while most activities contribute to exploitation [26,37]. In high-tech industries, the research activity is fundamental. A moderate level of marketing, manufacturing, or financing activities may create knowledge synergistic effects in achieving innovation ambidexterity [18,59-62]. As an increase in functional diversity, the share of research activity decreases, and the marginal synergy diminishes. Meanwhile, the managerial attention gets distributed with increased diversification in alliance network as too much engagement in exploitation activities means that less attention is distributed to knowledge exploration. Furthermore, from the perspective of transaction cost theory, the coordination and transaction costs get increased during the diversification of alliance 
function $[26,30,40]$. As such, functional diversity exceeding an optimal level does harm to exploratory innovation and decreases ambidexterity.

Combining the benefits derived from knowledge-based view and organizational learning theory and the drawbacks of marginal synergy diminishing and transaction cost increasing, we suggest that after initial enhancing innovation ambidexterity, the functional diversity may decrease exploration activities and lead to an imbalance between exploitative and exploratory innovation. We, therefore, put forward the following hypothesis:

Hypothesis 3. Alliance network functional diversity is associated with firm innovation ambidexterity that first increases and then decreases, forming an inverted $U$-shape.

All the three hypotheses and the research model are presented in Figure 1.

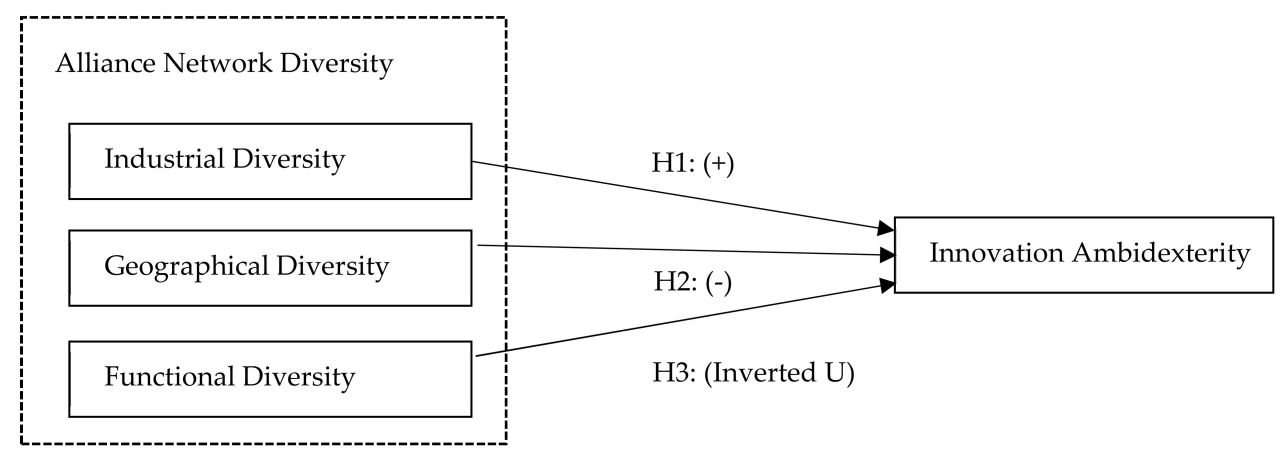

Figure 1. Research model and hypotheses.

\section{Method}

\subsection{Research Setting, Data and Samples}

We tested our hypotheses in the context of high-tech industries where technology is rapidly updated, and innovation ambidexterity is essential for firms' survival and sustainable development. Furthermore, high tech firms tend to have abundant patents, which guarantees the observation of patent-based innovation ambidexterity.

There are three steps for data collection. First, we retrieved all the high-tech alliances from Jan. 1, 2000 to Dec. 31, 2016, from the SDC Platinum Joint Ventures \& Alliances database. Such a database covers alliance records in four industries, namely computer, communications, electronics, and biopharmaceutical industries. There is a total of 35,614 alliance records. By checking manually, we found that there was overlap among computer, communications, electronics industries. Furthermore, a firm's alliances could be distributed among these three industries. Therefore, we merged these three industries as the electronic information industry and deleted the duplicated alliance records. In turn, we identified 29,668 alliance records. We extracted the information, including announcement date each alliance, name of alliance parties, four-digital Standard Industrial Classification (SIC) Code and geographical location of alliance parties, and function of each alliance. Second, we collected financial data like total assets from the Compustat database from 2004 to 2016. Third, we collected patent data, including four-digital International Patent Classification (IPC) Code, authority, and other information from the Derwent Innovation Index database from 2005 to 2017.

There are two steps for sample selection. First, firms with at least twenty alliances in total and at least one alliance in every five-year moving window from 2000 to 2016 were selected. There were 242 firms. Second, we retained listed companies, and 106 firms were selected, as listed below: NTT Corp., SoftBank Group Corp., Roche Holding AG, Nokia Oyj, Telefonaktiebolaget L.M. Ericsson, BT Group Plc, Vodafone Group Plc, GlaxoSmithKline Plc, Merck \& Co.,Inc., NEC Corp., Telefónica S.A., Sony Corp., Pfizer Inc., General Electric Co., HP Inc., AT\&T Inc., Cisco Systems Inc., Johnson \& Johnson, Eli Lilly \& Co., CK 
Hutchison Holdings Ltd., Intel Corp., Deutsche Telekom AG, Mitsui \& Co.,Ltd., AstraZeneca Plc, Bayer AG, Telstra Co.,Ltd., Novartis International AG, China Mobile Communications Corp., Sanofi S.A., Comcast Corp., Takeda Pharmaceutical Co.,Ltd., China United Network Communications Group Co., Ltd., Vivendi S.A., Amgen Inc., Sumitomo Corp., Hitachi Ltd., Adobe Systems Inc., Biogen Inc., The Walt Disney Co., China Telecom Co.,Ltd., Siemens AG, SK Telecom Co.,Ltd., Itochu Corp., SAP SE, Telenor ASA, Time Warner Cable Inc., Koninklijke Philips N.V., Samsung Electronics Co., Ltd., IBM Corp., Dentsu Inc., Evotec AG, KT Corp., HCL Technologies Ltd., Canon Inc., PLDT Inc., Salesforce.com, Inc., Fujitsu Ltd., Atos SE, Toyota Motor Corp., Toshiba Corp., LG Electronics Inc., Verizon Communications Inc., Eisai Co.,Ltd., ZTE Corp., Astellas Pharma Inc., WPP Plc, Tencent Holdings Ltd., Computer Sciences Corp., Sharp Corp., Advanced Micro Devices Inc., Mastercard Inc., Lenovo Group Ltd., Lockheed Martin Corp., Infosys Ltd., Lonza Group AG, Pitney Bowes Inc., Alcatel-Lucent S.A., Microsoft Corp., MorphoSys AG, Capgemini SE, Tele Atlas N.V., STMicroelectronics N.V., The Boeing Co., Hon Hai Precision Industry Co.,Ltd., Thales S.A., Larsen \& Toubro Ltd., Reliance Communications Ltd., Honeywell International Inc., Panasonic Corp., Bristol-Myers Squibb Co., Amazon.com, Inc., Mitsubishi Corp., Accenture Plc, Agilent Technologies, Inc., Akamai Technologies, Inc., Alphabet Inc., S\&P Global Inc., Mitsubishi Heavy Industries, Ltd., Wipro Ltd., Daiichi Sankyo Co.,Ltd., Abbott Laboratories, KDDI Corp., QIAGEN N.V., VEON Ltd., Raytheon Co., Nestle S.A. Data of 13 time periods were collected, and 1378 firm-year observations were involved in this study.

For each firm-year observation, we constructed the egocentric alliance network every five-year moving window with the help of Science of Science (Sci2) Tool and calculated alliance network industrial diversity, geographical diversity, and functional diversity with R programming. Furthermore, we calculated innovation ambidexterity with $\mathrm{R}$ programming.

\subsection{Variables}

\subsubsection{Dependent Variable}

Innovation ambidexterity. We used the method developed by Gilsing et al. [63] to define exploitative and exploratory innovation based on patent data. If one (or more) four-digital IPC code of a patent in the observation year is absent in the firm's existing technology classes before, the patent would be classified as exploratory innovation. If all the four-digital IPC codes of a patent in observation year have presented in the firm's existing technology classes before, the patent would be classified as exploitative innovation [64]. To overcome the limitations of the simple count, we weighted each patent by its number of patent authorities [65]. The exploitative innovation and exploratory innovation were calculated as follows:

$$
\begin{aligned}
& \text { ExploitativeInnovation }=\sum_{i=1}^{m} W_{i} \\
& \text { ExploratoryInnovation }=\sum_{i=1}^{n} W_{i}
\end{aligned}
$$

where $m$ denotes the number of exploitative patents granted a firm in an observation year, $n$ denotes the number of exploratory patents granted a firm in an observation year. $W_{i}$ represents the number of authorities of patent $i$. When the difference between exploratory innovation and exploitative innovation is less, it tends to ambidexterity [1]. Based on previous studies [66], we developed the relative dimension of innovation ambidexterity by dividing the difference between exploratory innovation and exploitative innovation by their sum. The formula of innovation ambidexterity is as follows:

$$
\text { Innovation ambidexterity }=\frac{\mid \text { Exploitative Innovation }- \text { Exploratory Innovation } \mid}{\text { Exploitative Innovation }+ \text { Exploratory Innovation }}
$$

Corresponding to the window period of the alliance network ( $\mathrm{t}-4$ period to $\mathrm{t}$ period), innovation ambidexterity of period $\mathrm{t}+1$ was calculated. 


\subsubsection{Independent Variables}

Alliance network diversity. We constructed alliance network diversity through the Teachman's index, also known as the Entropy Index, initially developed by Shannon. It is widely adopted in diversity research (e.g., [67]). The formula is as follows:

$$
H=-\sum_{i=1}^{s} P_{i}\left(\ln P_{i}\right)
$$

As for industrial diversity, we calculated it based four-digital SIC code. $\mathrm{P}_{\mathrm{i}}$ represents the proportion of partners that belong to SIC i. S represents the number of SIC categories. As for geographical diversity, $P_{i}$ represents the proportion of partners that belong to country i. $S$ represents the number of country categories. As for functional diversity, $\mathrm{P}_{\mathrm{i}}$ represents the proportion of alliance that involves activity i. $S$ represents the number of function categories. The value approaches 0 if all the partners or activities belong to a single category. It rises if they are more equally distributed over a richer number of categories. Following Lee and Chang's [61] approach wherein alliance relationships assumed to last for five years, we constructed alliance networks with five-year moving windows (i.e., 2000-2004, 2001-2005, ... 2012-2016) and calculated three diversity for each network.

\subsubsection{Control Variables}

To test hypotheses, we also controlled related variables as follows:

Firm size. Firm size has a significant effect on its innovation strategy and innovation capability [68]. Besides, firm size may correlate with the measure of alliance network diversity. An increment in R\&D employee size may increase the value of diversity variables. To specify the effect of network diversity, we controlled it. Following previous practice [61], we adopted log-transformed total assets as a proxy of firm size.

Firm age. Firm age positively associates with organizational learning [39], which could improve innovation ambidexterity. Furthermore, it causes organizational inertia [69], which could impede innovation ambidexterity. Considering that, we employed the firm age as the control variable.

Employee Number. The human capital of firms is also an important antecedent of innovation [2]. Thus, we controlled it. If the employee number reaches 10,000, the variable equals to 1 , otherwise 0 .

Industry dummy. Innovation ambidexterity may be associated with the industrial context as each industry has its innovation patterns and development stage. The sample firms in this study come from two industries, namely, the electronic information industry and the biopharmaceutical industry. Therefore, biopharmaceutical was controlled.

Region dummies. Innovation tends to be location-specific. Firms located in metropolitan areas are more innovative than those in peripheral areas [70]. As our samples mainly come from three regions, namely North America, Europe, and Asia and the Pacific Ocean, we included two dummies, and the default was Asia and the Pacific Ocean.

\subsection{Statistical Methods and Robust Tests}

According to the panel data, we adopted the panel regression model to test hypotheses. To decide whether the fixed effect or random effect regression model is appropriate, we conducted Hausman tests at both firm and time dimensions. According to the result, the difference in coefficients is not systematic at the firm dimensions, but at the time dimension. Therefore, we selected the time-fixed effect regression model [71]. To avoid reverse causality and to mitigate endogeneity, we adopted the longitudinal design [72], wherein independent variable measured in a prior period ( $t-4$ to $t$ ), control variables measured at $t$ year, and dependent variables measured at year $t+1$. To confirm the robustness, we regressed on innovation ambidexterity at year $t+2$ or $t+3$. We also recalculated innovation ambidexterity in several different ways and regressed on it. 


\section{Results}

\subsection{Regression Results}

The descriptive statistics of variables and their correlations are presented in Table 1. As shown, industrial diversity, geographical diversity, and functional diversity have different correlations with innovation ambidexterity. Industrial diversity has a positive correlation with innovation ambidexterity $(r=0.193, p<0.05)$. Geographical diversity has a negative correlation with innovation ambidexterity $(r=-0.128, p<0.05)$. Functional diversity also has a negative correlation with innovation ambidexterity, but the correlation is smaller than the geographical diversity $(r=-0.097, p<0.05)$. These three kinds of diversity have no significant or small correlations with each other $(r=0.040, p>0.05 ; r=0.229, p<0.05$; $r=0.315, p<0.05$, respectively). The control variables, namely firm size, firm age and employee number, have a negative correlation with innovation ambidexterity $(r=-0.331, p<0.05 ; r=-0.133$, $p<0.05 ; r=-0.205, p<0.05$, respectively).

Table 1. Mean, S.D., and correlations.

\begin{tabular}{|c|c|c|c|c|c|c|c|c|c|c|}
\hline & 1 & 2 & 3 & 4 & 5 & 6 & 7 & 8 & 9 & 10 \\
\hline $\begin{array}{l}\text { 1. Innovation } \\
\text { ambidexterity }\end{array}$ & 1 & & & & & & & & & \\
\hline 2. Industrial diversity & $0.193 *$ & 1 & & & & & & & & \\
\hline 4. Functional diversity & $-0.097 *$ & $0.229 *$ & $0.315 *$ & 1 & & & & & & \\
\hline 5. Firm size & $-0.331 *$ & $0.053 *$ & $0.242 *$ & $0.362 *$ & 1 & & & & & \\
\hline 6. Firm age & -0.133 * & -0.020 & $0.125 *$ & $0.140 *$ & $0.258 *$ & 1 & & & & \\
\hline 9. Europe & 0.017 & $-0.096 *$ & $0.343 *$ & -0.138 * & $-0.067^{*}$ & 0.030 & $-0.091 *$ & $0.196 *$ & 1 & \\
\hline 10. North_America & $-0.057 *$ & $0.089 *$ & $-0.369 *$ & -0.035 & 0.106 * & -0.051 & -0.017 & 0.015 & $-0.443 *$ & 1 \\
\hline Mean & 0.143 & 1.782 & 1.255 & 1.705 & 10.320 & 70.250 & 0.881 & 0.226 & 0.293 & 0.321 \\
\hline Std. Dev. & 0.211 & 1.449 & 0.371 & 0.461 & 1.514 & 48.320 & 0.324 & 0.419 & 0.455 & 0.467 \\
\hline Min & 0 & 0 & 0 & 0 & 4.328 & 5 & 0 & 0 & 0 & 0 \\
\hline Max & 1 & 22 & 2.171 & 2.848 & 14.16 & 236 & 1 & 1 & 1 & 1 \\
\hline
\end{tabular}

Table 2 presents the results of the time-fixed effect panel regression. All the model 1-5 were regressed on innovation ambidexterity. In model 1, control variables (firm size, firm age, employee number, industry dummies, and regional dummies) were entered. Next, independent variables, industrial diversity, geographical diversity, and functional diversity were entered in model 2, model 3, and model 4 separately. As we can see, the industrial diversity positively impacts innovation ambidexterity (see model $2, \beta=0.0289, p<0.001$ ). Thus, hypothesis 1 is supported. The geographical diversity negatively impacts innovation ambidexterity (see model $3, \beta=-0.0557, p<0.01$ ). Thus, hypothesis 2 is supported. The functional diversity has an inverted $U$ impact on innovation ambidexterity (see model $4, \beta 1=0.2045$, $p 1<0.001 ; \beta 2=-0.0746, p 12<0.001)$. Thus, hypothesis 3 is supported. All the independent variables are entered in model 5 together, and the results are consistent with models 2-4.

\subsection{Robust Test Results}

To verify the robustness of the conclusions, we regressed on firm innovation at year $t+2$ and $t+3$. Besides, we recalculated innovation ambidexterity in several different ways and regressed on it. Table 3 presents the results. In model 3, innovation ambidexterity at year $t+2$ was entered as the dependent variable. The regression results are consistent with previous conclusions. In model 2 , innovation ambidexterity at year $t+3$ was entered. The results suggest that most results are robust except that the impact of geographical diversity becomes not significant. In model 3, innovation ambidexterity based on IPC codes count was entered. The results are consistent. In model 4 , innovation ambidexterity based on unweighted patent count was entered. The results are consistent. As such, the empirical results of this study are robust. 
Table 2. Time-fixed panel regression results.

\begin{tabular}{|c|c|c|c|c|c|}
\hline & \multicolumn{5}{|c|}{ Innovation Ambidexterityt +1} \\
\hline & Model 1 & Model 2 & Model 3 & Model 4 & Model 5 \\
\hline Industrial diversity & & $\begin{array}{c}0.0289 * * * \\
(0.0037)\end{array}$ & & & $\begin{array}{c}0.0317^{* * *} \\
(0.0037)\end{array}$ \\
\hline Geographical diversity & & & $\begin{array}{c}-0.0557^{* *} \\
(0.0174)\end{array}$ & & $\begin{array}{c}-0.0444^{*} \\
(0.0178)\end{array}$ \\
\hline Functional diversity & & & & $\begin{array}{c}0.2045^{* * *} \\
(0.0562)\end{array}$ & $\begin{array}{c}0.2052 * * * \\
(0.0546)\end{array}$ \\
\hline Functional diversity-squared & & & & $\begin{array}{c}-0.0746^{* * *} \\
(0.0172)\end{array}$ & $\begin{array}{c}-0.0775^{* * *} \\
(0.0167)\end{array}$ \\
\hline Firm size & $\begin{array}{c}-0.0404^{* * *} \\
(0.0047)\end{array}$ & $\begin{array}{c}-0.0382 * * * \\
(0.0046)\end{array}$ & $\begin{array}{c}-0.0370 * * * \\
(0.0048)\end{array}$ & $\begin{array}{c}-0.0352 * * * \\
(0.0049)\end{array}$ & $\begin{array}{c}-0.0292^{* * *} \\
(0.0048)\end{array}$ \\
\hline Firm age & $\begin{array}{l}-0.0001 \\
(0.0001)\end{array}$ & $\begin{array}{l}-0.0001 \\
(0.0001)\end{array}$ & $\begin{array}{l}-0.0001 \\
(0.0001)\end{array}$ & $\begin{array}{l}-0.0000 \\
(0.0001)\end{array}$ & $\begin{array}{l}-0.0000 \\
(0.0001)\end{array}$ \\
\hline Employee number & $\begin{array}{l}-0.0138 \\
(0.0222)\end{array}$ & $\begin{array}{l}-0.0350 \\
(0.0218)\end{array}$ & $\begin{array}{l}-0.0116 \\
(0.0221)\end{array}$ & $\begin{array}{l}-0.0291 \\
(0.0223)\end{array}$ & $\begin{array}{c}-0.0513 \text { * } \\
(0.0218)\end{array}$ \\
\hline Biopharmaceutical & $\begin{array}{c}-0.0372^{* *} \\
(0.0144)\end{array}$ & $\begin{array}{c}-0.0184 \\
(0.0143)\end{array}$ & $\begin{array}{c}-0.0409 * * \\
(0.0144)\end{array}$ & $\begin{array}{c}-0.0565^{* * *} \\
(0.0155)\end{array}$ & $\begin{array}{c}-0.0424^{* *} \\
(0.0152)\end{array}$ \\
\hline Europe & $\begin{array}{l}-0.0099 \\
(0.0130)\end{array}$ & $\begin{array}{l}-0.0187 \\
(0.0127)\end{array}$ & $\begin{array}{c}-0.0223+ \\
(0.0135)\end{array}$ & $\begin{array}{l}-0.0152 \\
(0.0130)\end{array}$ & $\begin{array}{c}-0.0357^{* *} \\
(0.0131)\end{array}$ \\
\hline North_America & $\begin{array}{c}0.0041 \\
(0.0142)\end{array}$ & $\begin{array}{c}0.0027 \\
(0.0139)\end{array}$ & $\begin{array}{c}0.0184 \\
(0.0148)\end{array}$ & $\begin{array}{c}0.0021 \\
(0.0141)\end{array}$ & $\begin{array}{c}0.0112 \\
(0.0146)\end{array}$ \\
\hline Year dummies & Included & Included & Included & Included & Included \\
\hline Constant & $\begin{array}{c}0.5891 * * * \\
(0.0393)\end{array}$ & $\begin{array}{c}0.5330 * * * \\
(0.0391)\end{array}$ & $\begin{array}{c}0.6221 * * * \\
(0.0405)\end{array}$ & $\begin{array}{c}0.4363^{* * *} \\
(0.0574)\end{array}$ & $\begin{array}{c}0.4004^{* * *} \\
(0.0568)\end{array}$ \\
\hline $\mathrm{N}$ & 1303 & 1303 & 1303 & 1303 & 1303 \\
\hline R-squared & 0.1051 & 0.1458 & 0.1122 & 0.1210 & 0.1727 \\
\hline R-squared change & & 0.0407 & 0.0071 & 0.0159 & 0.0676 \\
\hline $\mathrm{F}$ & $25.1338^{* * *}$ & $31.2887^{* * *}$ & $23.1711^{* * *}$ & $22.0657^{* * *}$ & $26.7213^{* * *}$ \\
\hline
\end{tabular}

Notes: $+p<0.1,{ }^{*} p<0.05,{ }^{* *} p<0.01,{ }^{* * *} p<0.001$.

Table 3. Robust test regression results.

\begin{tabular}{|c|c|c|c|c|}
\hline & \multicolumn{4}{|c|}{ Dependent Variables } \\
\hline & Model 1 & Model 2 & Model 3 & Model 4 \\
\hline \multirow[t]{2}{*}{ Industrial diversity } & $0.0332^{* * *}$ & $0.0313^{* * *}$ & $0.0156^{* * *}$ & $0.0273^{* * *}$ \\
\hline & $(0.0038)$ & $(0.0039)$ & $(0.0034)$ & $(0.0037)$ \\
\hline \multirow[t]{2}{*}{ Geographical diversity } & $-0.0286+$ & -0.0267 & $-0.0445^{* *}$ & $-0.0542 * *$ \\
\hline & $(0.0168)$ & $(0.0200)$ & $(0.0161)$ & $(0.0180)$ \\
\hline \multirow[t]{2}{*}{ Functional diversity } & $0.1553^{* *}$ & $0.1086+$ & $0.1900 * * *$ & $0.1776^{* *}$ \\
\hline & $(0.0601)$ & $(0.0631)$ & $(0.0495)$ & $(0.0553)$ \\
\hline \multirow[t]{2}{*}{ Functional diversity-squared } & $-0.0625^{* * *}$ & $-0.0523^{* *}$ & $-0.0698^{* * *}$ & $-0.0647^{* * *}$ \\
\hline & $(0.0184)$ & $(0.0196)$ & $(0.0152)$ & $(0.0170)$ \\
\hline \multirow[t]{2}{*}{ Firm size } & $-0.0320^{* * *}$ & $-0.0286^{* * *}$ & $-0.0274^{* * *}$ & $-0.0324^{* * *}$ \\
\hline & $(0.0050)$ & $(0.0053)$ & $(0.0043)$ & $(0.0049)$ \\
\hline \multirow[t]{2}{*}{ Firm age } & -0.0001 & -0.0001 & $0.0003^{* *}$ & 0.0001 \\
\hline & $(0.0001)$ & $(0.0001)$ & $(0.0001)$ & $(0.0001)$ \\
\hline \multirow[t]{2}{*}{ Employee number } & $-0.0409+$ & $-0.0647^{* *}$ & 0.0053 & -0.0213 \\
\hline & $(0.0230)$ & $(0.0246)$ & $(0.0198)$ & $(0.0221)$ \\
\hline \multirow[t]{2}{*}{ Biopharmaceutical } & $-0.0358^{*}$ & $-0.0437^{* *}$ & $-0.0822^{* * *}$ & $-0.0339 *$ \\
\hline & $(0.0159)$ & $(0.0168)$ & $(0.0138)$ & $(0.0154)$ \\
\hline \multirow[t]{2}{*}{ Europe } & 0.0065 & -0.0014 & 0.0046 & 0.0103 \\
\hline & $(0.0153)$ & $(0.0163)$ & $(0.0132)$ & $(0.0148)$ \\
\hline \multirow[t]{2}{*}{ North_America } & $-0.0306^{*}$ & $-0.0311^{*}$ & $-0.0554^{* * *}$ & $-0.0584^{* * *}$ \\
\hline & $(0.0138)$ & $(0.0147)$ & $(0.0119)$ & $(0.0133)$ \\
\hline Year dummies & Included & Included & Included & Included \\
\hline \multirow[t]{2}{*}{ Constant } & $0.4419^{* * *}$ & $0.4827^{* * *}$ & $0.3144^{* * *}$ & $0.4206^{* * *}$ \\
\hline & $(0.0614)$ & $(0.0644)$ & $(0.0516)$ & $(0.0576)$ \\
\hline $\mathrm{N}$ & 1203 & 1103 & 1303 & 1303 \\
\hline R-squared & 0.1729 & 0.1661 & 0.1366 & 0.1524 \\
\hline Number of periods & 12 & 11 & 13 & 13 \\
\hline $\mathrm{F}^{1}$ & 24.6861 & 21.5514 & 20.2573 & 23.0137 \\
\hline
\end{tabular}

Notes: $+p<0.1,{ }^{*} p<0.05,{ }^{* *} p<0.01,{ }^{* * *} p<0.001$. 


\section{Conclusions and Discussion}

\subsection{Main Findings}

In this study, we test three types of alliance network diversity (geographical diversity, industrial diversity, and functional diversity) and investigate their differential roles in firm innovation ambidexterity construction. The main findings are as follows:

First, industrial diversity positively impacts innovation ambidexterity. We believe that the key to innovation ambidexterity construction is to enhance exploratory innovation. Derived from a knowledge-based view and organizational learning theory, we suppose that high industrial diversity, as the most critical source of knowledge diversity, may foster knowledge spillover, promote knowledge learning effect, and in turn, enhance firm exploratory innovation. This is consistent with previous opinions $[30,40,41]$. Grounded on transaction cost theory, we argue that industrial diversity decreases the conflicts of interest and learning races and increases in-depth knowledge learning. This is inconsistent with previous studies. Most of them emphasized the transaction cost generated by the disparity of different industrial regulations or routines. However, according to Jiang et al.'s argument [26], the fact that firms from the same industry are often competitors with an overlap in business backgrounds, innovation experiences, knowledge accumulation, and technological bases suggests that conflicts of interest may exist and learning races can happen among intra-industry alliance partners. To avoid conflicts and learning races, alliance monitoring, negotiation, and governance costs may increase. In contrast, allying with partners from diversified industries and with low competitiveness helps decrease such conflicts and costs [26]. As such, it is interpretable that industrial diversity improves in-depth exploratory learning by providing diversified knowledge and decreasing conflicts. In turn, it benefits firm innovation ambidexterity construction.

Second, geographical diversity negatively impacts innovation ambidexterity. Despite the potential advantages of geographically dispersed knowledge access and new market entry, the geographical diversity entails unique costs from the perspective of transaction cost theory. Similar opinions include that geographical diversity stems from the different geographical locations, cultures, institutional systems, and economic development between nations [48], which may increase coordination difficulties, decrease learning effectiveness [32], and impede exploration. Although value creation activities are more and more dispersed geographically, it is undeniable that very few counties own the core technological competence. For instance, according to OECD's report, the United States' patent applications for biotechnology account for one third to one-half of the world's total patent applications for a long time [73]. In the top 100 global technology leaders selected by Thomson Reuters, firms from the United States (45), China (17), and Japan (13) account for three quarters [74]. Another report issued Chinese Academy of Sciences suggests that only five countries apply for more than 100 patents in 5G technological field by the end of 2019, and the sum of China (1708), the United States (1513), Korea (551), Europe (243), and Japan (234) is more than $90 \%$ of the total applications [75]. In this respect, it may be hardly necessary for each firm to construct an alliance portfolio that involves partners from too many countries. Unlike the industrial diversity that indicates the divergence of the technological field, geographical diversity mainly facilitates the entry of diversified markets [26] and the adjustment to market regulations [34]. As such, it benefits the commercialization and exploitation of existing innovation outputs rather than the exploration of new technological innovation. In turn, it impedes firm innovation ambidexterity construction.

Third, functional diversity is associated with firm innovation ambidexterity that first increases and then decreases, forming an invert U-shape. Following previous literature $[26,27,56,57]$, we propose that alliance functions could be categorized as exploration (research, development) and exploitation (marketing, manufacturing, distribution, financing, etc.). For most high-tech firms, the research and development activity is emphasized a lot. A moderate level of functional diversity indicates the presence of both exploitative and exploratory value creation activities, which may create knowledge synergistic effects and thus, improves innovation ambidexterity. However, too high functional diversity 
may cause an imbalance. Intuitively, with an increase in functional diversity, alliance functions that relate to exploitation may be far more than the ones that contribute to exploration. As such, the limited effort gets distributed, the share of exploration activity decreases, and exploratory innovation may be damaged. Furthermore, the marginal synergy benefit of value creation activities diminishes, and the coordination and transaction cost across diversified value creation regulations increases [26,30,40], both of which also impede ambidexterity construction. Therefore, it is reasonable that functional diversity is associated with firm innovation ambidexterity that first increases and then decreases, forming an inverted U-shape.

Finally, two control variables also show significant impacts on innovation ambidexterity. The negative impact of firm size suggests that established firms with a big size may have strong organizational inertia that impedes exploration activities and hurts innovation ambidexterity. The negative impact of biopharmaceutical dummy suggests there is variance across different industries. Such variation may be caused by the fact as each industry has its unique patenting patterns and is at a different development stage. The detailed mechanism needs further investigation.

\subsection{Theoretical Contributions and Practical Implications}

There are two main theoretical contributions. First, it deepens our understanding of alliance network diversity, precisely, industrial diversity, geographical diversity, and functional diversity, by revealing their differential impacts and mechanisms. As indicated already, there are wide variations of classification and connotation of alliance network diversity in extant studies, and the differences of multiple diversity are still unclear. Besides, there is little consensus in the literature as to whether the effect of alliance network diversity on innovation is positive or negative, despite the considerable number of studies on this topic. Moreover, the interpretation of theories, including knowledge-based view, organizational learning theory, and transaction cost theory, varies a lot across different kinds of network diversity and lacks effective integration in existing empirical studies [27]. In this study, grounding on the literature review of kinds of alliance network diversity and in-depth analysis of their connotation, we identify three representative dimensions (industrial diversity, geographical diversity, and functional diversity) that have the most abundant connotation and smallest correlation. By integrating the knowledge-based view, organizational learning theory, and transaction cost theory and analyzing the unique connotation of each network diversity, we propose different theoretical arguments and empirically reveal their differential roles. As such, this study enriches alliance network diversity research and guide for future research.

Second, this study deepens the understandings of innovation ambidexterity by developing a patent-based measure and investigating its antecedents. Organizational ambidexterity has gained much attention in innovation research $[1,3,37]$. However, previous empirical studies either take exploitative innovation and exploratory innovation as two dependent variables [65,76] or measure the ambidexterity through questionnaires [77]. These two measures cannot objectively reveal the connotation of innovation ambidexterity. Besides, most of them take organizational ambidexterity as an independent variable and investigate its impacts on firm performance [78]. Despite that network factors including network composition, network embeddedness, position, tie strength, and network dynamics being investigated, the extant studies about the impacts of alliance network diversity on ambidexterity are still at an early stage. In this study, we develop a new measure based on the exploitative and exploratory patent count. As patent data is more objective and available, it can enhance reliability and feasibility. Such a measurement can be duplicated in future research. Using this measure, we empirically investigate the differential influences and mechanisms of multiple alliance network diversity, and thus, enrich the antecedents research of innovation ambidexterity. We highlight that the key to innovation ambidexterity construction is exploratory innovation as exploitative innovation can be easily achieved for firms with accumulated knowledge in fields, while exploratory innovation is more challenging and requires more effort. As such, it deepens the understandings of the connotation and antecedents of firm innovation ambidexterity. 
The results also provide some practical suggestions about alliance network configuration and innovation ambidexterity construction for high-tech firms. First, high-tech firms should enhance alliance industrial diversity by allying with firms from both related industries and unrelated industries. Partners from related industries are particularly relevant in terms of knowledge and regulations, and thus benefits exploitation. Partners from unrelated industries provide opportunities to screen new technological possibilities in areas unrelated to prior knowledge accumulation, thus foster exploration. Second, high-tech firms should select partners from a few technologically advanced countries when engaging in international alliances. It is believed that cross-broader partners provide the potential advantages of geographically dispersed knowledge access. However, it is undeniable that very few counties own the core technical knowledge. High geographical diversity may not bring more knowledge benefits. Furthermore, it leads to higher transaction costs. As such, the focal firms should identify the sources of core competence and concentrate on several counties. Third, high-tech firms should build a diverse alliance portfolio that involves both exploratory functions such as R\&D alliances and exploitative functions such as marketing, manufacturing, and financing. However, as indicated already, the key to ambidexterity construction is exploration, and too much exploitation may distribute limited attention and effort. As such, the focal firm should main a moderate level of functional diversity.

\subsection{Limitations and Further Studies}

Despite significant theoretical and practical implications, there are still some limitations that should be addressed in future research. First, taking the SDC database as the only source of alliance data is not comprehensive. Further studies could enrich the data by collecting news reports or referring to historical texts. Second, patent count based indicators cannot reflect the entire connotation of firm innovation ambidexterity. Further studies could involve other indicators based on surveys. Third, sample firms are limited to listed companies with a long history of alliance participation. As startups or small and medium-sized enterprises (SMEs) are lack of formal and structured alliance strategies, the expansibility of the findings in this study needs further verification. Fourth, this study is conducted in a high-tech context. Such results may not be generalized to traditional industries. However, the research design could be replicated and applied in further studies.

Author Contributions: Conceptualization, G.Z. \& C.T.; Data curation, G.Z.; Formal analysis, G.Z.; Funding acquisition, C.T. \& Y.Q.; Methodology, G.Z.; Project administration, Y.Q.; Resources, C.T.; Supervision, C.T.; Writing-Original draft, G.Z.; Writing-Review \& editing, G.Z., C.T. \& Y.Q. All authors have read and agreed to the published version of the manuscript.

Funding: This research was funded by National Natural Science Foundation of China, grant number 71673264, $71673135,71974096,71974178,71932009$. This research was also funded by Fundamental Research Funds for the Central Universities. The APC was funded by 71673264, 71673135, 71974096, 71974178, 71932009.

Conflicts of Interest: The authors declare no conflict of interest.

\section{References}

1. He, Z.L.; Wong, P.K. Exploration vs. exploitation: An empirical test of the ambidexterity hypothesis. Organ. Sci. 2004, 15, 481-494. [CrossRef]

2. Lin, H.E.; McDonough, E.F.; Lin, S.J.; Lin, C.Y. Managing the exploitation/exploration paradox: The role of a learning capability and innovation ambidexterity. J. Prod. Innovat. Manag. 2013, 30, 262-278. [CrossRef]

3. March, J.G. Exploration and exploitation in organizational learning. Organ. Sci. 1991, 2, 71-87. [CrossRef]

4. Argote, L.; Ren, Y.Q. Transactive memory systems: A microfoundation of dynamic capabilities. J. Manag. Stud. 2012, 49, 1375-1382. [CrossRef]

5. O'Reilly, C.A.I.; Tushman, M.L. Ambidexterity as a dynamic capability: Resolving the innovator's dilemma. Res. Organ. Behav. 2008, 28, 185-206. [CrossRef]

6. Simsek, Z.; Heavey, C.; Veiga, J.F.; Souder, D. A typology for aligning organizational ambidexterity's conceptualizations, antecedents, and outcomes. J. Manag. Stud. 2009, 46, 864-894. [CrossRef] 
7. Boronat-Navarro, M.; García-Joerger, A. Ambidexterity, Alliances and Environmental Management System Adoption in Spanish Hotels. Sustainability 2019, 11, 5815. [CrossRef]

8. García-Granero, A.; Fernández-Mesa, A.; Jansen, J.J.; Vega-Jurado, J. Top management team diversity and ambidexterity: The contingent role of shared responsibility and CEO cognitive trust. Long Range Plann. 2018, 51, 881-893. [CrossRef]

9. Raffaelli, R.; Glynn, M.A.; Tushman, M. Frame flexibility: The role of cognitive and emotional framing in innovation adoption by incumbent firms. Strateg. Manag. J. 2019, 51, 1013-1039. [CrossRef]

10. Ramachandran, I.; Lengnick-Hall, C.A.; Badrinarayanan, V. Enabling and leveraging ambidexterity: influence of strategic orientations and knowledge stock. J. Knowl. Manag. 2019, 23, 1136-1156. [CrossRef]

11. Smith, W.K.; Tushman, M.L. Managing strategic contradictions: A top management model for managing innovation streams. Organ. Sci. 2005, 16, 522-536. [CrossRef]

12. Ardito, L.; Petruzzelli, A.M.; Dezi, L.; Castellano, S. The influence of inbound open innovation on ambidexterity performance: Does it pay to source knowledge from supply chain stakeholders? Available online: https://www.sciencedirect.com/science/article/abs/pii/S0148296318306593?via\%3Dihub (accessed on 20 December 2018).

13. Cammarano, A.; Michelino, F.; Caputo, M. Open innovation practices for knowledge acquisition and their effects on innovation output. Technol. Anal. Strateg. Manag. 2019, 31, 1-17. [CrossRef]

14. Stettner, U.; Lavie, D. Ambidexterity under scrutiny: Exploration and exploitation via internal organization, alliances, and acquisitions. Strateg. Manag. J. 2014, 35, 1903-1929. [CrossRef]

15. Bresciani, S.; Ferraris, A.; Del Giudice, M. The management of organizational ambidexterity through alliances in a new context of analysis: Internet of Things (IoT) smart city projects. Technol. Forecast. Soc. Chang. 2018, 136, 331-338. [CrossRef]

16. Petruzzelli, A.M. Trading knowledge for status: Conceptualizing R\&D alliance formation to achieve ambidexterity. Technol. Forecast. Soc. Chang. 2019, 145, 36-42.

17. Lee, J.; Kim, N. Know yourself and find your partners: Achieving ambidexterity and inter-organizational collaboration. Manag. Res. Rev. 2019, 42, 1333-1352. [CrossRef]

18. Feng, Y.; Teng, D.; Hao, B. Joint actions with large partners and small-firm ambidexterity in asymmetric alliances: The mediating role of relational identification. Int. Small Bus. J. 2019, 37, 689-712. [CrossRef]

19. Cenamor, J.; Parida, V.; Wincent, J. How entrepreneurial SMEs compete through digital platforms: The roles of digital platform capability, network capability and ambidexterity. J. Bus. Res. 2019, 100, 196-206. [CrossRef]

20. Tsai, H.T.; Ren, S. Antecedents of strategic ambidexterity in the context of internationalisation: a panel study of Taiwan Small and median-sized enterprises. Technol. Anal. Strateg. Manag. 2019, 31, 986-1001. [CrossRef]

21. Vlasa, R.; Vlasb, C. The Role of Internal and Network Constraints on Alliance Ambidexterity Decisions in Technology Intensive Industries. Asia Pac. J. Inf. Syst. 2016, 26, 299-321. [CrossRef]

22. Zhang, J.A.; Edgar, F.; Geare, A.; O'Kane, C. The interactive effects of entrepreneurial orientation and capability-based HRM on firm performance: The mediating role of innovation ambidexterity. Ind. Mark. Manag. 2016, 59, 131-143. [CrossRef]

23. Tiwana, A. Do bridging ties complement strong ties? an empirical examination of alliance ambidexterity. Strateg. Manag. J. 2008, 29, 251-272. [CrossRef]

24. Lin, Z.; Yang, H.; Demirkan, I. The performance consequences of ambidexterity in strategic alliance formations: Empirical investigation and computational theorizing. Manag. Sci. 2007, 53, 1645-1658. [CrossRef]

25. Wassmer, U. Alliance portfolios: A review and research agenda. J. Manag. 2010, 36, 141-171. [CrossRef]

26. Jiang, R.; Tao, Q.; Santoro, M. Alliance portfolio diversity and firm performance. Strateg. Manag. J. 2010, 31, 1136-1144. [CrossRef]

27. Lee, D.; Kirkpatrick-Husk, K.; Madhavan, R. Diversity in alliance portfolios and performance outcomes: A meta-analysis. J. Manag. 2017, 43, 1472-1497. [CrossRef]

28. Cui, A.S.; O'Connor, G. Alliance Portfolio Resource Diversity and Firm Innovation. J. Mark. 2012, 76, 83-93. [CrossRef]

29. Wuyts, S.; Dutta, S. Benefiting from alliance portfolio diversity: The role of past internal knowledge creation strategy. J. Manag. 2014, 40, 1653-1674. [CrossRef]

30. Huang, S.; Chen, J.; Liang, L. How open innovation performance responds to partner heterogeneity in China. Manag. Decis. 2018, 56, 26-46. [CrossRef] 
31. Sampson, R.C. R\&D alliances and firm performance: The impact of technological diversity and alliance organization on innovation. Acad. Manag. J. 2007, 50, 364-386.

32. Goerzen, A.; Beamish, P.W. The effect of alliance network diversity on multinational enterprise performance. Strateg. Manag. J. 2005, 26, 333-354. [CrossRef]

33. Phelps, C. A longitudinal study of the influence of alliance network structure and composition on firm exploratory innovation. Acad. Manag. J. 2010, 53, 890-913. [CrossRef]

34. Van Beers, C.; Zand, F. R\&D cooperation, partner diversity, and innovation performance: An empirical analysis. J. Prod. Innovat. Manag. 2014, 31, 292-312.

35. Lavie, D.; Rosenkopf, L. Balancing exploration and exploitation in alliance formation. Acad. Manag. J. 2006, 49, 797-818. [CrossRef]

36. Peng, X.; Wu, D. Tie diversity, ambidexterity and upgrading of the latecomer firm in global production networks. Chin. Manag. Stud. 2013, 7, 310-327. [CrossRef]

37. Lucena, A.; Roper, S. Absorptive capacity and ambidexterity in R\&D: Linking technology alliance diversity and firm innovation. Eur. Manag. Rev. 2016, 13, 159-178.

38. Ardito, L.; Peruffo, E.; Natalicchio, A. The relationships between the internationalization of alliance portfolio diversity, individual incentives, and innovation ambidexterity: A microfoundational approach. Technol. Forecast. Soc. Chang. 2019, 148, 119714. [CrossRef]

39. Cohen, W.M.; Levinthal, D.A. Absorptive capacity: A new perspective on learning and innovation. Adm. Sci. Q. 1990, 35, 128-152. [CrossRef]

40. Filiou, D.; Massini, S. Industry cognitive distance in alliances and firm innovation performance. RED Manag. 2017, 48, 422-437.

41. Raesfeld, A.V.; Geurts, P.; Jansen, M.; Boshuizen, J.; Luttge, R. Influence of partner diversity on collaborative public R\&D project outcomes: A study of application and commercialization of nanotechnologies in the Netherlands. Technovation 2012, 32, 227-233.

42. Sarpong, O.; Teirlinck, P. The influence of functional and geographical diversity in collaboration on product innovation performance in SMEs. J. Tech. Transf. 2018, 43, 1667-1695. [CrossRef]

43. Jacobs, J. The Economy of Cities, Random House; The New York Times: New York, NY, USA, 1969.

44. Zollo, M.; Winter, S.G. Deliberate learning and the evolution of dynamic capabilities. Organ. Sci. 2002, 13, 339-351. [CrossRef]

45. Doz, Y.; Hamel, G. Alliance Advantage: The Art of Creating Value Through Partnering; Harvard Business School Press: Boston, MA, USA, 1998.

46. Teece, D.J. Competition, cooperation and innovation: Organizational arrangements for regimes of rapid technological progress. J. Econ. Behav. Organ. 1992, 18, 1-25. [CrossRef]

47. Eisenhardt, K.M.; Schoonhoven, C.B. Resource-based view of strategic alliance formation: Strategic and social effects in entrepreneurial firms. Organ. Sci. 1996, 7, 136-150. [CrossRef]

48. Lavie, D.; Miller, S.R. Alliance portfolio internationalization and firm performance. Organ. Sci. 2008, 19, 623-646. [CrossRef]

49. Hsieh, W.L.; Ganotakis, P.; Kafouros, M.; Wang, C. Foreign and domestic collaboration, product innovation novelty and firm growth. J. Prod. Innovat. Manag. 2018, 35, 652-672. [CrossRef]

50. Parkhe, A. Partner nationality and the structure performance relationship in strategic alliances. Organ. Sci. 1993, 4, 301-324. [CrossRef]

51. Tung, R.L. Managing cross-national and intra-national diversity. Hum. Resour. Manag. 1993, 32, 461-477. [CrossRef]

52. Beise, M. Lead markets: Country-specific drivers of the global diffusion of innovations. Res. Policy 2004, 33, 997-1018. [CrossRef]

53. Tiwari, R.; Herstatt, C. Assessing India's lead market potential for cost-effective innovations. J. Indian Bus. Res. 2012, 4, 97-115. [CrossRef]

54. Lavie, D. The competitive advantage of interconnected firms: An extension of the resource-based view. Acad. Manag. Rev. 2006, 31, 638-658. [CrossRef]

55. Lu, J.W.; Beamish, P.W. Partnering Strategies and Performance of SMEs' International Joint Ventures. J. Bus. Ventur. 2006, 21, 461-486. [CrossRef]

56. Prahalad, C.K.; Hamel, G. The Core Competence of the Corporation. Harvard Bus. Rev. 1990, 68, 79-91.

57. Hagedoorn, J. Understanding the rationale of strategic technology partnering: inter-organizational modes of cooperation and sectoral differences. Strateg. Manag. J. 1993, 14, 371-385. [CrossRef] 
58. Hoang, H.; Rothaermel, F. Leveraging internal and external experience: Exploration, exploitation, and R\&D project performance. Strateg. Manag. J. 2010, 31, 734-758.

59. Kong, T.; Li, G.; Feng, T.; Sun, L. Effects of marketing-manufacturing integration across stages of new product development on performance. Int. J. Prod. Res. 2015, 53, 2269-2284. [CrossRef]

60. Brettel, M.; Heinemann, F.; Engelen, A.; Neubauer, S. Cross-functional integration of R\&D, marketing, and manufacturing in radical and incremental product innovations and its effects on project effectiveness and efficiency. J. Prod. Innovat. Manag. 2011, 28, 251-269.

61. Lee, J.; Chang, Y.B. Interplay between internal investment and alliance specialization in R\&D and marketing. Ind. Mark. Manag. 2014, 43, 813-825.

62. Covin, J.G.; Eggers, F.; Kraus, S.; Cheng, C.F.; Chang, M.L. Marketing-related resources and radical innovativeness in family and non-family firms: A configurational approach. J. Bus. Res. 2016, 69, 5620-5627. [CrossRef]

63. Gilsing, V.; Nooteboom, B.; Vanhaverbeke, W.; Duysters, G.; van den Oord, A. Network embeddedness and the exploration of novel technologies: Technological distance, betweenness centrality and density. Res. Policy 2008, 37, 1717-1731. [CrossRef]

64. Wang, C.; Rodan, S.; Fruin, M.; Xu, X. Knowledge networks, collaboration networks, and exploratory innovation. Acad. Manag. J. 2014, 57, 484-514. [CrossRef]

65. Guan, J.C.; Liu, N. Exploitative and exploratory innovations in knowledge network and collaboration network: A patent analysis in the technological field of nano-energy. Res. Policy 2016, 45, 97-112. [CrossRef]

66. Dayan, M.; Di Benedetto, C.A. Team intuition as a continuum construct and new product creativity: The role of environmental turbulence, team experience, and stress. Res. Policy 2011, 40, 276-286. [CrossRef]

67. Zhang, G.; Tang, C. How R\&D partner diversity influences innovation performance: An empirical study in the nano-biopharmaceutical field. Scientometrics 2018, 116, 1487-1512.

68. Hsueh, C.C.; Chen, D.Z. A taxonomy of patent strategies in Taiwan's small and medium innovative enterprises. Technol. Forecast. Soc. Chang. 2015, 92, 84-98. [CrossRef]

69. Barron, D.N.; West, E.; Hannan, M.T. A time to grow and a time to die-Growth and mortality of credit unions in New York City, 1914-1990. Am. J. Sociol. 1994, 100, 381-421. [CrossRef]

70. Porter, M.E.; Stern, S. Innovation: Location matters. Sloan Manag. Rev. 2001, 42, 28-36.

71. Hausman, J.A. Specification Tests in Econometrics. Econometrica 1978, 46, 1251-1271. [CrossRef]

72. Singh, H.; Kryscynski, D.; Li, X.; Gopal, R. Pipes, pools, and filters: how collaboration networks affect innovative performance. Strateg. Manag. J. 2016, 37, 1649-1666. [CrossRef]

73. OECD. A Framework for Biotechnology Statistics. Available online: https://www.oecd.org/sti/emergingtech/aframeworkforbiotechnologystatistics.htm (accessed on 12 January 2020).

74. Thomson Reuters. Top 100 Global Tech Leaders. Available online: https://www.thomsonreuters.com/ content/dam/ewpm/documents/thomsonreuters/en/pdf/reports/thomson-reuters-top-100-global-techleaders-report.pdf (accessed on 12 January 2020).

75. Lu, L.; Liao, Q.; Li, N. An Industrial and Technical Analysis Report of 5G. High-Technol. Ind. 2019, 8, 40-47.

76. Yan, Y.; Guan, J.C. Social capital, exploitative and exploratory innovations: the mediating roles of ego-network dynamics. Technol. Forecast. Soc. Chang. 2018, 126, 244-258. [CrossRef]

77. Lin, H.E.; McDonough, E.F. Cognitive frames, learning mechanisms, and innovation ambidexterity. J. Prod. Innovat. Manag. 2014, 31, 170-188. [CrossRef]

78. Dunlap, D.R.; Parente, R.C.; Geleilate, J.M. Managing the complexities of innovation ambidexterity: The role of supplier relationships. Acad. Manag. Proc. 2017, 10461. [CrossRef]

(C) 2020 by the authors. Licensee MDPI, Basel, Switzerland. This article is an open access article distributed under the terms and conditions of the Creative Commons Attribution (CC BY) license (http://creativecommons.org/licenses/by/4.0/). 